\title{
Аналіз розподілу параметрів і ефективності енергетичних процесів в гідравлічних і аеродинамічних системах
}

\author{
В. А. Арсірій, О. Г. Бутенко, С. Ю. Смик, О. В. Кравченко \\ Одеський національний політехнічний університет, пр. Шевченка 1, м. Одеса, 65004, Україна \\ $\triangle$ e-mail: arsiri.v.a@ opu.ua, ORCID ID: $\underline{\text { https://orcid.org/0000-0003-3617-8487 }}$
}

\begin{abstract}
Аналіз методів побудови енергетичних характеристик насосів і вентиляторів показав особливості подання проиесів в аеродинамічних системах і способу регулювання подачі вентиляторів або димососів в зоні розрядження. Показано, щзо протиріччя структурно-параметричних моделей аеродинамічних систем є причиною проблем експлуатації енергетичних об'єктів. Головною проблемою теплової енергетики є «обмеження потужності котлів» через недостатню продуктивність аеродинамічних систем. Виконано порівняння двох варіантів підвищення потужності котлів за рахунок збільшення продуктивності аеродинамічних систем. 1 варіант - заміна вентилятора або його електродвигуна на більш потужні забезпечує збільшення подачі повітря в котел на 48\%, при цьому питомі витрати енергї на привід збільшуються з 1,2 до 2,7. Зміни ефективності при заміні вентилятора виконується тільки за показником ККД вентилятора, який зберігає високі значення ККД ${ }_{1}=\kappa К Д_{2}=82,5 \%$. Для збільшення подачі повітря в котел запропоновано новий метод за рахунок вдосконалення проточних частин і аеродинамічних процесів у допоміжних елементах системи без заміни вентилятора. При иьвому на перше місие при розрахунку ефективності системи можна віднести питоме зниження витрат енергії на привід вентилятора. Коригування проточних частин допоміжного обладнання аеродинамічній системи котла дозволила збільшити подачу вентилятора більш ніж на 35\%. Питомі витрати енергї знижені з 1,2 до величини 1,05. Однак ККД вентилятора істотно зменшився з ККД $=82,5$ до ККД $2=47 \%$. Таким чином ККД вентилятора не відображає ефективність аеродинамічної системи. Для правильної оцінки ефективності аеродинамічних систем запропоновано розраховувати два показника ефективності. ККД вентилятора показує ефективність перетворення електричної енергії в аеродинамічну. Для оцінки ефективності динамічних процесів запропоновано розробити уніфіковані показники потенціалу і дії. Ставлення динамічної складової потужності або дії до вхідного потенціалу може характеризувати ефективність аеродинамічних процесів в системі.
\end{abstract}

Ключові слова: Ефективність, ККД вентилятора, опір, аеродинамічна система, обмеження потужності котлів.

doi: https://doi.org/10.15673/ret.v55i3.1576

(C) The Author(s) 2019. This article is an open access publication

This work is licensed under the Creative Commons Attribution 4.0 International License (CC BY) http://creativecommons.org/licenses/by/4.0/

\section{1. Вступ}

Більшість підприємств теплової енергетики проектувалися в середині минулого століття. Тривалий період експлуатації вимагає аналізу їх конкурентоспроможності і переосмислення їх ролі в загальному балансі енергетичного комплексу. Тенденції розвитку теплової енергетики пов'язують не тільки з будівництвом нових об'єктів, а в більшій мірі з оновленням існуючих енергетичних підприємств. Спосіб заміни обладнання отримав назву «Інтенсифікація» $[1,2]$. Позитивний ефект від заміни обладнання пов'язують з економією коштів при збереженні інфраструктури. Однак, досвід інтенсифікації для аеродинамічних систем виявив суттєві протиріччя: заміна вентиляторів збільшує подачу, проте призводить до збільшення витрат енергії на привід при парадоксальному збереженні високих значень ККД вентиляторів. Аналіз причин цих протиріч показав недостатність параметрів в моделях динамічних процесів, а також і некоректність існуючих показників ефективності в ході проектування гідравлічних і аеродинамічних систем в рамках енергетичних технологій.

\section{2. Два варіанти підвищення продуктивності аеродинамічних систем}

У статті виконано порівняльний аналіз двох варіантів реновації аеродинамічних систем (АС) 3 метою збільшення продуктивності: 1 варіант - використання відомого способу інтенсифікації за рахунок заміни вентилятора на більш потужний, при цьому оцінка ефективності виконується за по- 
казником ККД вентилятора; 2 варіант - за рахунок застосування нової методики вдосконалення аеродинамічних процесів у допоміжних елементах системи.

Нова методика полягає у виявленні структури потоків і вдосконаленні динамічних процесів. В першу чергу це стосується зміни геометрії проточних частин допоміжного обладнання та з'єднувальних елементів: поворотів, колекторів, вхідних або вихідних ділянок, тобто за рахунок зниження опору в системі $[3,4]$. Новий спосіб реновації АC дозволяє збільшувати ії продуктивність без заміни нагнітачів або електродвигунів, при цьому на перше місце в розрахунку економічного ефекту реновацій можна віднести економію енергії на власні потреби (витрат енергії на привід нагнітача), а також економію коштів на виконання незначних змін проточних частин у порівнянні з витратами при заміні обладнання. Такого роду реновації $\mathrm{AC}$ можна позначити терміном «ефективізація». Однак потрібно розробити показники ефективності динамічних процесів: як обладнання та його окремих елементів, так і всієї системи в цілому.

\section{1. Аналіз структурно-параметричних схем гі- дравлічних і аеродинамічних систем}

Методи представлення процесів в аеродинамічних і гідравлічних системах (ГС) об'єднані в розділі фізики - механіка рідин і газів. Основним обладнанням ГС і АС є насоси, вентилятори (нагнітачі повітря) і димососи, в яких електрична енергія, витрачена на привід, перетворюється у вихідний потенціал динамічних систем (величину тиску Р або натиск Н). Тиск в більшій мірі витрачається на подолання опорів або продавлювання потоків через систему.

Методи представлення енергетичних процесів в ГС і АС розвивалися паралельно і на сьогоднішній день невиправдано подібні. В ГС при зниженні тиску (збільшенні розрядження) перед нагнітачем може виникати кавітація на лопатках насосів. Тому в зоні розрядження ГС не розміщують обладнання. Самим простими для регулювання продуктивності динамічних систем $є$ регулюючі пристрої (РП) дисипативного типу, в яких зміна подачі виконується закриттям, тобто збільшенням опору. Тому в гідравлічних системах РП розташовують обов'язково в зоні тиску, так як в разі зниження тиску може виникати кавітація.

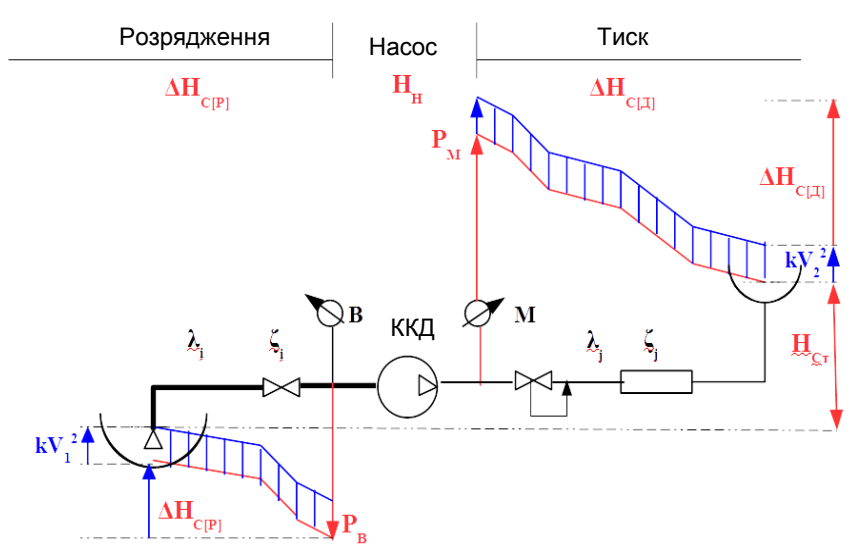

\section{Рисунок 1 - Структурно-параметрична схема гідравлічної системи}

При проектуванні ГС і АС представлення i вибір параметрів виконується на основі графіків енергетичних характеристик нагнітачів, які розробляють на основі випробувань нагнітачів на спеціальних експериментальних стендах [5]. На графіку енергетичних параметрів основними $є$ три характеристики залежно від головного параметра подачі - $Q$ : напірна характеристика нагнітача $H_{\text {н }}=f(Q)$, характеристика витрат енергії (потужності електродвигуна) на привід $N_{\text {эл.н }}=f(Q)$ і характеристика ККД нагнітача ККД

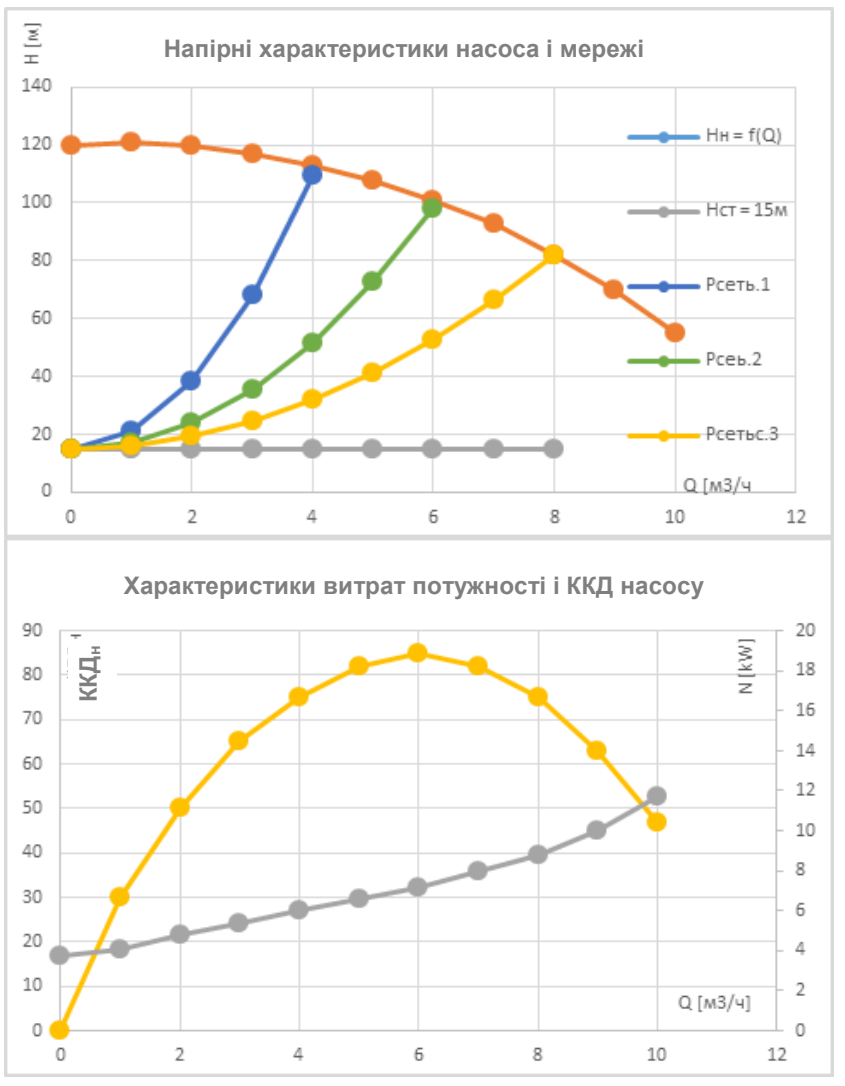

Рисунок 2 - Енергетичні характеристики насосів і гідравлічної мережі 
Характеристики нагнітачів показують діапазон можливої зміни параметрів динамічних систем, які гарантує виробник нагнітачів. Для визначення реальних параметрів в працюючій системі використовують графічний метод. Для реалізації графічного методу проектувальник розраховує втрати

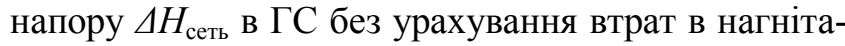
чі. Сума втрат напору і висоти підйому рідини дозволяє розрахувати напірну характеристику мережі $H_{\text {сеть }}=f(Q)$. Зручною одиницею виміру напору в ГС $\epsilon$ метри водяного стовпа [м.в.ст].

$$
H_{\text {сеть }}=H_{\Gamma}+\Delta H_{\text {сеть }}
$$

Визначення реальних параметрів роботи ГС легше і наочніше виконувати на графіку експериментальних енергетичних характеристик насоса $H_{\text {нас }}=f(Q)$, де додатково будують розраховану напірну характеристику мережі $H_{\text {сеть }}=f(Q)$. Перетин цих двох графіків дає робочу (розрахункову) точку РТ, яка визначає енергетичний баланс в системі при заданій подачі.

Графічне представлення реальних параметрів роботи ГС дозволяе також виконувати вибір і оптимізацію параметрів роботи нагнітачів в полі графіків 3-х зазначених характеристик. Для оптимізації використовується оптимум характеристики ККД насоса, хоча насосне обладнання є тільки частиною гідравлічної системи. Вважається, що максимальне значення ККД нагнітача визначає максимальну ефективність роботи ГС. Це припущення формує завдання оптимізації тільки в рамках вибору параметрів нагнітачів. Однак, аналіз енергозберігаючих заходів в ГС показав некоректність припущення про те, що максимальне ККД нагнітачів автоматично забезпечує максимальну ефективність АС в цілому.

При проектуванні ГС насоси можуть створити напір в десятки або сотні метрів, при цьому в зоні розрядження через небезпеку виникнення кавітації забезпечують мінімальні втрати напору. Тому при розрахунку характеристики мережі в ГС втрати напору в зоні розрядження не виділяють в окрему складову.

Особливістю аеродинамічних систем є можливість рівноцінно встановлювати обладнання i регулюючі пристрої (РП) як в зоні тиску, так і в зоні розрядження. Величини тиску і розрядження в АC через стискання середовищ, що перекачуються, істотно менше, ніж в ГС, тому кращими термінами для позначення одиниць виміру $P \epsilon-$ [мм.в.ст] або декаПаскалі [даПа]. Далі замість те- рміна повний напір будемо використовувати - повний тиск, а замість втрати напору $\Delta H$ - втрати тиску $\Delta P$. Втрати тиску в аеродинамічній мережі необхідно розраховувати як в зоні тиску, так і в зоні розрядження. Для цього АС можна умовно розділити на 3 ділянки.

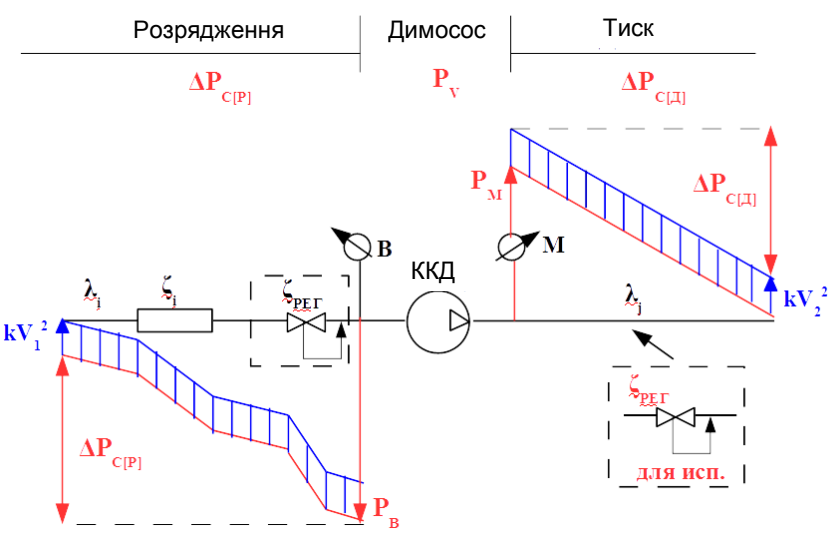

Рисунок 3 - Структурно-параметрична схема аеродинамічній мережі

Перша ділянка - зона розрядження мережі до

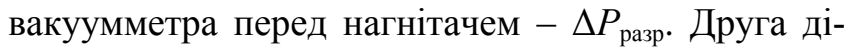
лянка - зона дії нагнітача. Сьогодні для зони дії нагнітача проектувальник не визначає втрати і не виконує будь-яких розрахунків, а використовує енергетичні характеристики нагнітачів з каталогів, розроблені на основі випробувань на експериментальних стендах. Треття ділянка - зона тиску мережі від манометра після нагнітача до кінця $\mathrm{AC}$ -

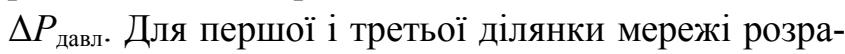
хунок втрат тиску виконують використовуючи довідкові дані про місцеві опори $\zeta$ і коефіцієнти тертя $l$ на ділянках довжиною 1 [6]. Основою розрахунку $є$ динамічна складова повного напору $\rho V^{2} / 2$ з величиною швидкості $V$ на кожній розрахунковій ділянці АС.

$$
\begin{gathered}
P_{\text {сеть }}=\Delta P_{C_{[P]}}+\Delta P_{\text {С ГД] }}= \\
=\left(\sum \zeta_{i}+\sum l_{i} l_{i} \mid d\right) \rho V_{i}^{2} / 2+\left(\sum \zeta_{j}+\sum l_{j} l_{j} \mid d\right) \rho V_{j}^{2} / 2
\end{gathered}
$$

Останнім часом регулювання подачі як димососів так і вентиляторів здійснюється РП, розташованими до нагнітачів в зоні розрядження. У цьому принципова відмінність АС від ГС. На відміну від ГС для побудови сімейства напірних характеристик вентиляторів і димососів на експериментальних стендах використовують РП як в зоні розрядження, так і зоні тиску. Для побудови окремих напірних характеристик регулюючий пристрій в зоні тиску регулюють від закритого поло- 
ження до повного відкриття. Сімейство напірних характеристик будується при дискретному закритті РП в зоні розрядження (див. рис. 3) $0 \% ;-10 \% ; \ldots-60 \%$. Такого виду характеристики потрібно переглянути, так як в реальних АС регулююча арматура 3 напірної сторони відсутня. Така невідповідність формує складнощі в розумінні процесів в АC і протиріччя при аналізі і обгрунтуванні енергозберігаючих заходів.

\section{2. Проблема обмежень потужності котлів}

Через суперечності структурно-параметричних моделей $\mathrm{AC}$ і реальних динамічних процесів виникає ряд проблем експлуатації енергетичних об'єктів. Сьогодні головною (масовою) проблемою теплової енергетики $є$ «обмеження потужності котлів». Цей термін з'явився в 80-х роках для аналізу причин: чому максимальне навантаження котлів на 10 - 35\% менше їх номінальної або паспортної теплової потужності. При обгрунтуванні обмежень потужності котлів в якості причини найчастіше заявляють недостатню продуктивність нагнітачів: вентиляторів або димососів, які разом з їх електродвигунами поєднують терміном «тягодуттьові механізми» (ТДМ). Якщо не вистачає подачі дуттьових вентиляторів, то в обгрунтуванні заявляють «обмеження потужності котла по дуттю», якщо не вистачає тяги димососів, то це «обмеження потужності котла по тязі». Таким чином найбільш проблемними в котельних установках $\epsilon$ аеродинамічні системи.

У статті наведено два варіанти вирішення проблеми зняття обмежень потужності котлів по дуттю: 1 - на основі способу інтенсифікації за рахунок заміни вентилятора на більш потужний; 2 на основі ефективізаціі, коли подача вентилятора збільшується за рахунок вдосконалення і коригування аеродинамічних процесів.

Для аналізу двох варіантів необхідно розглянути існуючі методики проектування АС. Головною вимогою вибору нагнітачів для аеродинамічних систем $\epsilon$ забезпечення максимальної подачі $Q^{*}$ з запасом не менше $10 \%$. Перша умова $-Q_{\text {вент }}=$ $=1,1 Q^{*}$. Для цього вентилятори і димососи повинні забезпечувати такий повний напір $P_{\mathrm{v}}$, який при заданій подачі $Q^{*}{ }_{i}$ компенсує втрати напору $\Delta P_{\text {сеть }}$ на подолання опорів в мережі. Для оптимізації параметрів АС існують ще дві умови:

Друга умова - за робочу ділянку напірної характеристики вентилятора повинна прийматися та частина, на якій значення ККД вентилятора знаходиться в діапазоні $\eta_{\text {вент }} \geq 0,9 \eta_{\text {вент } \max }[3$, п.2.15].

Треття умова - витрати електричної енергії $\Delta \mathrm{N}_{\text {эл }}$ на привід вентилятора повинні бути мінімальними. Однак умова мінімальних витрат енергії лише декларується, так як не оговорені показники, що характеризують цю умову. Перелічені умови забезпечення заданої подачі $Q^{*}$ і дві умови оптимізації параметрів аеродинамічних трактів можна назвати правилами вибору ТДМ при проектуванні аеродинамічних систем $[4,5]$.

$$
\begin{gathered}
\mathrm{PT} \rightarrow Q \rightarrow P_{\mathrm{V} . \text { н }} \equiv P_{\text {сеть }} \\
P_{\mathrm{V} . \mathrm{H}} \equiv \eta_{\text {вент }} \geq 0,9 \eta_{\text {вент } \max }
\end{gathered}
$$

Розглянемо 1-й варіант підвищення продуктивності (подачі) АС для зняття обмежень потужності котлів КВГМ-50 по дуттю на основі існуючих правил проектування. Для номінальної теплової потужності котла $N_{\text {T.ном }}=58 \mathrm{MBT}\left(Q_{\text {T.Ном }}=50\right.$ Гкал) необхідно забезпечити подачу повітря для горіння палива $Q^{*} \approx 65$ тис.. ${ }^{3} /$ год. Однак, вентилятор ВДН-15 (з оборотами $980 \mathrm{xв}^{-1}$ ), який рекомендований для даного типу котла, забезпечує подачу не більше $Q_{0} \approx 43$ тис.м ${ }^{3} /$ год (див. т. А0). Через недостатню подачу повітря для горіння реальна теплова потужність котла не перевищує $N_{\text {T.Реал }}=40 \mathrm{MBT}$, а обмеження потужності котельні установки становить $\Delta N_{\text {T.Ном }}=N_{\text {T.Ном }}-N_{\text {T.Реал }}=58-40=18 \mathrm{MBT}$.

Для вибору варіанта заміни механізмів АC скористаємося формулою перерахунку витрат енергії на привід подібних вентиляторів при зміні основних параметрів [5, 6].

$$
N_{1}=N_{o}\left(\frac{n_{1}}{n_{0}}\right)^{3}\left(\frac{D_{1}}{D_{0}}\right)^{5} \frac{\rho_{1}}{\rho_{0}} \frac{\eta_{0}}{\eta_{1}} .
$$

Аналіз зміни витрат енергії на роботу вентилятора 3 використанням формули 4 показав, що збільшення продуктивності вентилятора за рахунок його заміни на більший, призводить до підвищення витрат на привід пропорційно 5-го ступеня відношення діаметрів робочого колеса. Кращим варіантом збільшення подачі вентилятора $є$ підвищення швидкості обертання, що призведе до збільшення витрат енергії на привід пропорційно 3-го ступеня зростання числа обертів. Тому сьогодні пріоритетним вважається варіант збільшення подачі вентилятора шляхом заміни електродвигуна вентилятора 3 метою збільшення швидкості його обертання. Аналіз зміни параметрів роботи АС 
котла при заміні електродвигуна показаний на рисунку 4.

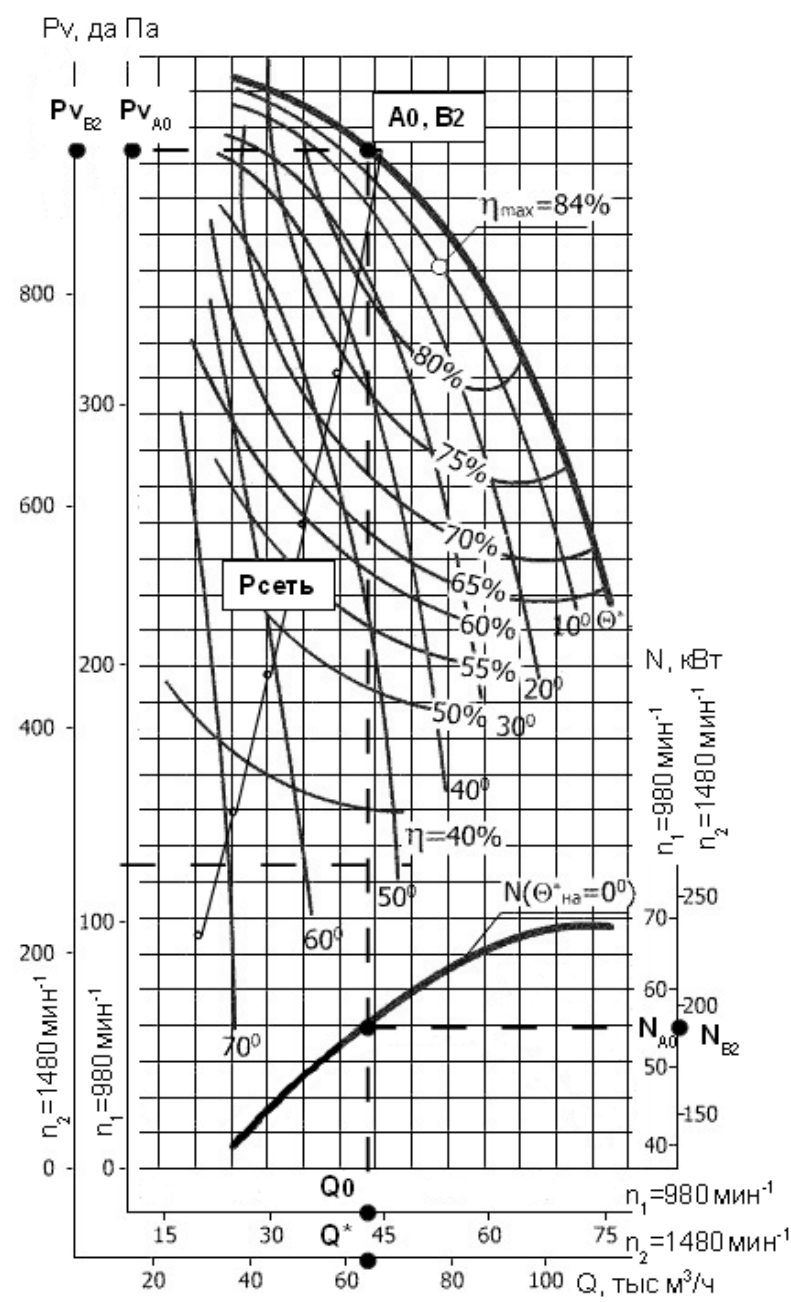

Рисунок 4 - Енергетичні параметри дуттьового тракту котла КВГМ-50 в полі характеристик вентилятора ВДН-15 при двох швидкостях обертання

На рисунку 4 видно, що при незмінній характеристиці мережі $P_{\text {сеть }}=f(Q)$ за рахунок заміни приводу (електродвигуна) вентилятора і підвищення його швидкості обертання від $n_{l}=980 \mathrm{xв}^{-1}$ (точка АТ) до $n_{2}=1480 \mathrm{xB}^{-1}$ (точка В2) подача повітря збільшується в 1,48 рази (з $Q_{0} \approx 44$ тис.м ${ }^{3} /$ год до необхідної величини $Q^{*}=65$ тис.м ${ }^{3} /$ год). Це дозволяе збільшити максимальну теплову потужність котла $N_{\text {T.ном }}=58 \mathrm{MBT}\left(Q_{\text {T.ном }}=50\right.$ Гкал).

Такий варіант збільшення подачі повітря практично не використовується, так як призводить до появи ряду проблем експлуатації - підвищеного рівня шуму, вібрації тягодуттьових механізмів. Але головною перешкодою реалізації такого роду інтенсифікації в аеродинамічній системі котла є істотне збільшення витрат енергії на привід (табл. 1).
Таблиця 1 - Збільшення максимальної теплової потужності котла КВГМ-50 за рахунок заміни електродвигуна вентилятора ВДн-15

\begin{tabular}{|l|c|c|c|}
\hline Найменування & $\begin{array}{c}\text { Розмір- } \\
\text { ність }\end{array}$ & $\begin{array}{c}\text { До } \\
\text { рек. }\end{array}$ & $\begin{array}{c}\text { Після } \\
\text { рек. }\end{array}$ \\
\cline { 3 - 4 } & Точка А0 & Точка В2 \\
\hline Число обертів & хв $^{-1}$ & 980 & 1480 \\
\hline $\begin{array}{l}\text { Максимальна по- } \\
\text { тужність котла }\end{array}$ & $\begin{array}{c}\text { МВт } \\
\text { Гкал }\end{array}$ & $\begin{array}{c}40 \\
34,5\end{array}$ & $\begin{array}{c}58 \\
50\end{array}$ \\
\hline $\begin{array}{l}\text { Подача вентиля- } \\
\text { тора, Qв }\end{array}$ & $10^{3}$ мรод $^{3} /{ }^{2}$ & 45 & 65 \\
\hline ККД вентилятора & $\%$ & 0,825 & 0,825 \\
\hline $\begin{array}{l}\text { Витрати на привід } \\
\text { вентилятора, Nэл }\end{array}$ & кВт & 55 & 180 \\
\hline Питомі витрати, $k_{N}$ & Вт/м ${ }^{3}$ & 1,2 & 2,77 \\
\hline
\end{tabular}

ККД вентилятора при подачі $Q^{*}$, що забезпечує номінальну потужність котла, залишається незмінним і прийнятно високим $\eta_{\text {вентА } 0}=\eta_{\text {вентВ } 2}=$ $=0,825$. Однак витрати енергії на привід вентилятора збільшуються $3 N_{A}=55$ кВт до величини $N_{B}>180$ кВт. Таким чином, при збільшенні швидкості обертання електродвигуна виникає протиріччя: ККД вентилятора в точці А0 і В2 зберігає високе значення, однак для збільшення подачі повітря в котел в 1,48 рази витрати енергії на привід непропорційно (значно) збільшуються в 3,27 рази. Для аналізу третьої умови оптимізації АС доцільно використовувати додатковий коефіцієнт питомих витрат енергії вентилятора $k_{N}$, який можна розрахувати як відношення витрат енергії на привід нагнітача $\Delta N_{э л}$ до відповідної подачі $Q$.

$$
k_{N}=N / Q .
$$

Розрахунок коефіцієнта питомих витрат $k_{N}$ показали, що збільшення подачі шляхом збільшення швидкості обертання вентилятора $є$ енерговитратним - при збільшенні подачі повітря в 1,48 рази, питомі витрати підвищилися від величини $k_{N(A)}=1,25$ до $k_{N(B)}=2,77$. Таке непропорційне підвищення витрат потужності на дуття пояснює причину того, що вже більше 30 років проблема обмежень потужності котлів залишається без вирішення. А відсутність в літературі і навіть в інтернеті інформації про проблему обмежень потужності котлів говорить про те, що методичні вказів- 
ки 3 обгрунтування обмежень потужності енергетичних об'єктів $[2,3,4]$ фактично звільнили енергетичні підприємства від виконання складного завдання підвищення продуктивності АС і підвищення теплової потужності котлів до номінальної.

\section{3. Підвищення продуктивності аеродинаміч- них систем із забезпеченням енергозбереження}

У 2006 році був розроблений і реалізований енергозберігаючий варіант зняття обмежень потужності котлів КВГМ-50 по дуттю тільки за рахунок зниження втрат напору в аеродинамічній мережі шляхом коригування аеродинаміки в елементах дуттьового тракту на основі фізичного моделювання 3 використанням нового методу візуальної діагностики структури потоків (МВДСП) [7, 8].

В першу чергу це стосується як основного обладнання нагнітачів повітря, димососів, так і допоміжних елементів системи. Такого роду зміни в енергетичних процесах вимагають перейти від укрупненого вибору нагнітачів із забезпеченням високих значень ККД цих нагнітачів до підвищення ефективності систем в цілому. Така методика реновації може бути доповненням до інтенсифікації, яку можна представляти терміном «ефективізація».

Для аналізу впливу опорів обладнання і елементів АC розроблена нова структурнопараметрична схема процесів.

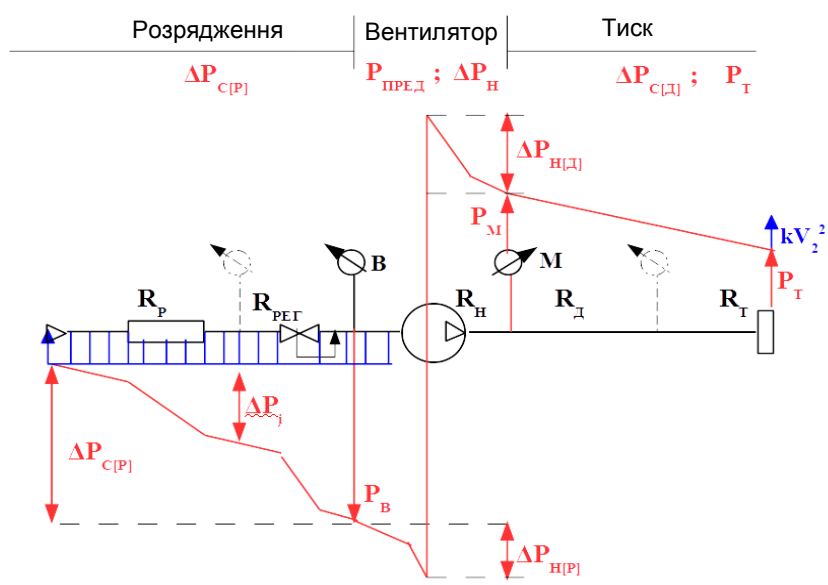

\section{Рисунок 5 - Структурно-параметрична схема аеродинамічної системи}

Аналіз втрат напору в дуттьовому тракті показав, що найбільші втрати напору створюють пальники типу РГМГ - технологічні втрати - Рт. Пальники РГМГ були замінені на пальники типу «CHT» 3 меншим опором [9]. Заміна пальників знизила втрати напору в дуттьовому тракті котла більш ніж на 50\%.

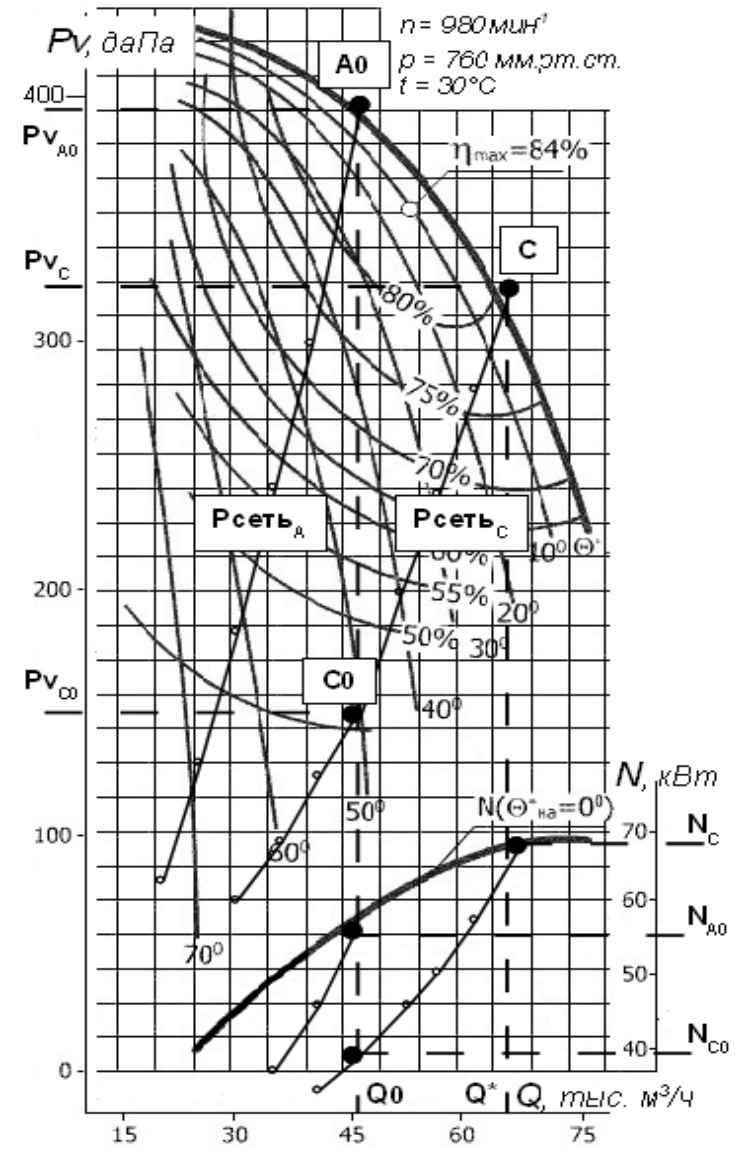

Рисунок 6 - Параметри дуттьового тракту котла КВГМ-50 до реконструкиії і після

Коригування аеродинаміки проточних частин допоміжного обладнання $\mathrm{AC}$ котла дозволило збільшити подачу вентилятора більш ніж на $35 \%$. На рисунку 6 в полі характеристик вентилятора ВДН-15 з оборотами $n=980 \mathrm{xв}^{-1}$ представлені дві характеристики мережі $P_{\text {сеть А }}$ - до реконструкції і

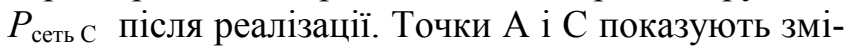
ни параметрів АС.

Після коригування аеродинаміки елементів дуттьового тракту котла КВГМ-50 на новій харак-

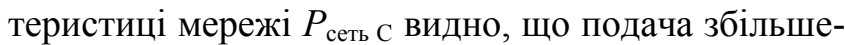
на до величини $Q^{*} \approx 65$ тис.м ${ }^{3} /$ год.

Коригування аеродинаміки було виконано для вдосконалення структури потоку у вхідному патрубку вентилятора ВДН-15. Вимірювання проточної частини усунули дисипативні зони і зменшили опір у вхідному патрубку від $\zeta_{1}=1,57$ до $\zeta_{2}=0,23$.

Коригування аеродинаміки в поворотах потоку на $90^{\circ}$ дозволяє знизити опір проточної частини більш ніж в 4 рази. Тобто необхідно виконувати аналіз ефективності не тільки основного обладнання - вентиляторів або димососів, але й допоміжних елементів системи - проточних частин обладнання: поворотів, колекторів, вхідних і вихідних елементів. Тобто необхідно розробити ефективність динамічних процесів системи порівняну 3 ефективністю вентиляторів. 
Таблица 2 - Поліпшення параметрів дуттьового тракту котла КВГМ-50 за рахунок коригування аеродинамічної системи (при збереженні вентилятора ВДН-15 і ел. двигуна $n=$ const $=980$ об/хв)

\begin{tabular}{|c|c|c|c|c|}
\hline \multirow[t]{2}{*}{ Найменування } & \multirow[t]{2}{*}{ Розмір } & \multirow{2}{*}{$\begin{array}{c}\text { До } \\
\text { реконструкції } \\
\text { Точка А0 }\end{array}$} & \multicolumn{2}{|c|}{$\begin{array}{c}\text { Після коригування } \\
\text { аеродинаміки }\end{array}$} \\
\hline & & & Точка С0 & Точка C \\
\hline $\begin{array}{l}\text { Максимальна потужність } \\
\text { котла }\end{array}$ & $\begin{array}{l}\text { МВт } \\
\text { Гкал }\end{array}$ & $\begin{array}{c}40 \\
34,5\end{array}$ & $\begin{array}{c}40 \\
34,5\end{array}$ & $\begin{array}{l}58 \\
50\end{array}$ \\
\hline Подача вентилятора $Q$ & $10^{3} \mathrm{~m}^{3} /$ год & 45 & 45 & 65 \\
\hline Число оборотів ел. двигуна & $\mathrm{XB}^{-1}$ & 980 & 980 & 980 \\
\hline ККД вентилятора & $\%$ & 0,825 & 0,47 & 0,79 \\
\hline $\begin{array}{l}\text { Витрати ел. енергії } \\
\text { на привід вентилятора }\end{array}$ & кВт & 55 & 39 & 68 \\
\hline $\begin{array}{l}\text { Питомі витрати } \\
\text { на привід вентилятора }\end{array}$ & $\mathrm{BT} / \mathrm{M}^{3}$ & 1,2 & 0,87 & 1,05 \\
\hline
\end{tabular}

Після виконання реконструкції дуттьового тракту коригування та оптимізація аеродинамічних процесів забезпечила збільшення діапазону регулювання теплового навантаження котлів. Максимальна потужність котлів $N_{\text {T.Ном }}$ яка важлива в період низьких температур, збільшена від 40 МВт до 58 МВт.

\section{4. Аналіз системних показників ефективності}

Представлений аналіз двох варіантів реновації AC: 1 - інтенсифікація параметрів за рахунок заміни основного обладнання на більш потужне і 2 підвищення системної ефективності за рахунок застосування нової методики вдосконалення проточних частин і коригування аеродинамічних процесів показав необхідність розширення і уніфікації параметрів ГС і АC, які використовуються при розробці енергозберігаючих заходів. Очевидним фактом $\epsilon$ те, що припущення про достатність оцінки ефективності енергосистем тільки за показником ККД нагнітачів є помилковим, що стримує розробку енергозберігаючих заходів [10].

Удосконалення проточних частин забезпечує зниження опорів при русі рідин і газів, тобто при реалізації динамічних процесів. Однак, динамічні процеси в проточних частинах сьогодні характеризуються тільки величинами опорів, які не можна порівняти $з$ показником ККД нагнітачів, де відбувається перетворення або трансформація різних видів енергії. Тому, грунтуючись виключно на оптимізації ефективності нагнітачів, спроби знизити витрати енергії в гідравлічних або аеродинамічних системах безперспективні. Енергетичні процеси в ГС і АС необхідно розділити на два принципово різних види.
Добре розроблений перший вид енергетичних процесів - перетворення або трансформація різних видів енергії (механічної, гідравлічної електричної, теплової та ін.) в одному пристрої. У різних енергетичних системах саме те обладнання, в якому здійснюється перетворення різних видів енергії вважають основним. В ГС це насоси, в АС це вентилятори і димососи. Розрахунок ККД нагнітачів або ефективності перетворення витраченої електричної потужності в потужність аеродинамічного потоку заснований на тому факті, що в розрахунках використовується єдина одиниця виміру [Ватт], щоб представити потужність $N$ як інтенсивність роботи $A / t$ [Дж/с] для різних видів енергії. Для аналізу поняття потужність скористаємося ідеєю автора поняття енергія Аристотеля про те, що енергію можна представити як добуток двох складових: потенціалу $P$ на величину дії $D$. Тобто формули розрахунку потужності різних видів енергії також уніфіковані $N=P \times D$.

Уніфікація одиниці вимірювання потужності $N$ і уніфікація формул розрахунку потужності дозволяє аналізувати ККД нагнітачів, а краще ефективність $\eta$ перетворення різних видів енергії в основному обладнанні.

$$
\begin{gathered}
\eta_{\text {н }}=N_{\text {гидр }} / N_{\text {эл }}= \\
=\mathrm{g} H \times \rho Q / U \times I[\mathrm{BT}] /[\mathrm{BT}] .
\end{gathered}
$$

При проектуванні помилково вважається, що достатньо показника ефективності тільки основного обладнання для оптимізації параметрів системи в цілому. Тому в аеродинамічній системі ефективність перетворення електричної енергії, витраченої в електродвигуні на формування обертання робочого колеса, в результаті формує аеродинамі- 
чну енергію потоку повітря в котел і має значення $\eta_{\text {н }}=N_{\text {гидр }} / N_{\text {эл }}=0,8$. Однак настільки висока ефективність вентилятора характеризує ефективність перетворення електричної енергії в динамічну тільки в самому насосі, а не в ГС в цілому.

Другий тип енергетичних процесів характеризує реалізацію потенціалу $P$ в динамічну складову Д в рамках одного виду енергії. Можна виходити 3 припущення, що динамічні процеси при русі рідин і газів реалізуються за рахунок потенціалу $P$ (вихідного тиску). Важливою частиною енергетичних процесів $\epsilon$ дві складові, які можна розглядати як корисну роботу в системі: 1 - динамічна складова повного напору і 2 - висота підйому рідини Нст (див. рис 1) або необхідний технологічний тиск Рт (див. рис. 3), якщо ця друга частина корисних параметрів присутня в системі. Неминучою частиною енергетичних процесів $€$ втрати тиску на подолання опорів $R$ проточних частин. Сьогодні величини опорів за своїми значеннями не можна порівняти 3 показником ККД або ефективності

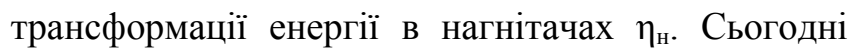

опори, судячи по величинам (опір вентиля $\varsigma_{в}=5$ ), показують недосконалість проточних частин, хоча теоретично вони побічно характеризують зворотну величину ефективності або провідності.

Для розробки показника, що характеризує ефективність динамічних процесів $\varphi$ можна виходити 3 того, що при відсутності опорів ефективність динамічних процесів буде максимальною і у відносній формі $\varphi=1$. При відсутності опорів динамічна Д складова буде максимальною - граничною і при правильному методичному оформленні повинна дорівнювати вихідному потенціалу $P$ в системі. Тобто коефіцієнт динамічної ефективності $\varphi$ може характеризувати якість реалізації динамічних процесів як відношення динамічної складової до початкового потенціалу $\varphi=Д / P=1 /(1+R)$, або як зворотне значення опору. Головною умовою можливості використання такого методу розрахунку ефективності динамічних процесів $\epsilon$ уніфікація або рівноцінність і рівна розмірність величин потенціалу та динамічної складової.

Таблиця 3 - Аналіз показників ефективності в гідродинамічній системі.

\begin{tabular}{|c|c|}
\hline \multicolumn{2}{|c|}{ Енергія $E \Rightarrow$ Робота $A$ [Дж] $\Rightarrow$ Потужність $N=A / t \quad[B m]=[Д ж / c]$} \\
\hline Трансформація енергії & Динамічні процеси \\
\hline Потужність $N=P \times Д \quad[\mathrm{Bm}]$ & $Д \equiv P$ \\
\hline$N_{э л}=U \times I$ & $I=U / R \equiv \varphi_{э л} U$ \\
\hline$N_{\text {zидp }} \equiv H g \times \rho Q$ & $\rho Q \equiv \varphi_{\text {гидр }} S(2 g H)^{0,5}$ \\
\hline$\eta_{m p}=N_{\text {гидр }} / N_{\text {эл }}=0,8$ & $\varphi_{\text {сидp }} \equiv 1 /(1+R) \equiv \rho Q / S(2 g H)^{0,5}=0,4$ \\
\hline$\eta_{s i s t}=$ & $4=0,32$ \\
\hline
\end{tabular}

Таким чином, методика, запропонована для розрахунку ефективності динамічних процесів гідравлічних систем, $є$ реалізовною. Однак, необхідно відзначити! Якщо в електричних системах в розрахунках потужності параметри потенціалу напруги перемножуються 3 параметром дії - силою струму, то в динамічних процесах (в законі Ома) ці ж показники відповідають перетворенню потенціалу в динамічну складову 3 урахуванням показника опору.

Для гідродинаміки формула розрахунку динамічних процесів (формула Торрічеллі) використовує в якості параметра потенціалу - величину напору $\mathrm{g} H$, а параметр дії може бути представлений динамічною складовою повного напору $0,5 r V 2$, але не в повній мірі відповідають параметрам уніфікованої форми розрахунку потужності де динамічна складова представлена масою середовища, що перекачується - $r Q$. Тому в формулах розрахунку гідравлічної потужності і формулах, що представляють гідродинамічні процеси знак рівності «=» замінений на знак відповідності «झ». Для розробки уніфікованих методів і моделей для ГС і АС необхідно вирішити складну задачу рівнозначності і рівного розміру величин потенціалу $P$ і динамічної складової Д.

\section{3. Висновки}

Методи проектування та оптимізації параметрів аеродинамічних систем мають протиріччя при розробці проектів збільшення продуктивності вентиляторів і димососів. Інтенсифікація або заміна нагнітачів на більш потужні забезпечує збільшен- 
ня подачі зі збереженням високих значень ККД нагнітачів, проте витрати потужності на роботу нагнітачів ростуть непропорційно, що є перешкодою вирішення проблеми обмежень потужності котлів.

Для вирішення проблеми підвищення продуктивності ГС і АС і вирішення проблеми обмежень потужності котлів по дуттю і тязі розроблена нова концепція підвищення продуктивності і системної ефективності тягодуттьових трактів і механізмів за рахунок оптимізації або коригування геометрії проточних частин відповідно до результатів візуальної діагностики структури потоків. Нова концепція розрахунку ефективізації динамічних процесів в аеродинамічних і гідравлічних системах потребує аналізу і перегляду показників ефективності як основного, так і допоміжного обладнання.

\section{Література}

1. Башаров М.М. Энергосберегающая модернизация ректификационной установки выделения фенола // Нефтегазовое дело. - 2011. - № 2. - С. 136-146.

2. Лаптев А.Г., Николаев Н.А., Башаров М.М. Методы интенсификации и моделирования тепломассообменных процессов. Учебно-справочное пособие. М.: «Теплотехник», 2011. - 335 с.

3. Крачунов, Хр. Комплексно проектиране на технически системи. Технически университет - Варна, 2010 ;
4. Арсирий, В.А. Повышение производительности котлов за счет снятия ограничений мощности по тяге и дутью [Текст] / В.А. Арсирий, В.А. Смирнова, Е.А. Арсирий // Вісник НТУ «ХПІ». Серія: Енергетичні та теплотехнічні процеси й устаткування. Харків : НТУ «ХПІ», 2016. - № 10(1182). - С. 78-84. - doi: 10.20998/2078-774X.2016.10.12.

5. Теплотехнические испытания котельных установок / В. И. Трембовля, Е. Д. Фингер, А. А. Авдеева. 2-е изд., перераб. и доп. - М.: Энергия, 1977. - 296 с. 6. Idelchik I.E. Shteynberg M.O. Handbook of hydraulic resistance. Engineering. $-672 \mathrm{p}$.

7. Пат. PST 5.812.423 USA Method of determining for working media motion and designing flow structures for same // Maisotsenko V. S., Arsiri V. A.. - Publ. 22.09.1998

8. Бутенко О.Г., Смик С.Ю. Підвищення коефіцієнта корисної дії центрального ежектора за неоптимальних режимів роботи. Науковий вісник Національного гірничого університету. - Дніпропетровськ, 2015. № 2. - С. 57-61.

9. Абдулин М.З., Дубовик В.С. Струйно-нишевая технология сжигания топлива на объектах енергетики. // 《ННовости теплоснабжения〉, 2004. - № 11. C. $19-22$.

10. Филлипов Г.А., Меламед Л.Э., Тропкина А.И. Иерархия моделей анализа коллекторных систем и макромасштабный анализ // Изв. вузов. Проблемы энергетики. - 2010. - № 5-6. - С. 3-16. 325.

Отримана в редакції 04.05.2019, прийнята до друку 07.06.2019

\title{
Analysis of the parameters distribution and the efficiency of energy processes in hydraulic and aerodynamic systems
}

\author{
V. A. Arsiri, O. H. Butenko, S. Ju. Smyk, O. V. Kravchenko
}

Odessa National Polytechnic University, Shevchenko av., 1, Odessa, 65044, Ukraine

$\triangle$ e-mail: arsiri.v.a@opu.ua, ORCID ID: https://orcid.org/0000-0003-3617-8487

An analysis of the methods for constructing the energy characteristics of pumps and fans showed the features of the representation of processes in aerodynamic systems and the method of regulating the supply of fans or smoke exhausters in the negative pressure or vacuum zone. It is shown, that the contradictions of the structural-parametric models of aerodynamic systems are the cause of the problems of the operation of energy facilities. The main problem of thermal power engineering is the "boiler capacity limitations" due to the insufficient performance of aerodynamic systems. A comparison is made of two options for increasing the power of boilers by increasing the performance of aerodynamic systems. Option 1 - replacing the fan or its electric motor with more powerful ones provides an increase in air supply to the boiler by 48\%, while the specific energy consumption for the drive increases to 2.7. Changes in efficiency when replacing a fan are determined by the fan efficiency only, which maintains high values. To increase the air supply to the boiler, a new method has been proposed by improving the flow parts and aerodynamic processes in the auxiliary elements of the system without replacing the fan. In this case, the first place in calculating the efficiency of the system 
can be attributed to the specific reduction in energy costs for the fan drive. The adjustment of the flow parts of the auxiliary equipment of the boiler aerodynamic system allowed increasing the fan flow by more than $35 \%$. The specific energy consumption is reduced to 1.05. However, the fan efficiencyhas decreased significantly. Thus, the fan efficiency does not correctly reflect the efficiency of the aerodynamic system. o correctly assess the effectiveness of aerodynamic systems, it is proposed to calculate two performance indicators. Fan efficiency shows the efficiency of converting electrical energy into aerodynamic. To assess the effectiveness of dynamic processes it is proposed to develop unified indicators of potential and action. The ratio of the dynamic component of power or action to the initial potential can characterize the efficiency of aerodynamic processes in the system.

Keywords: Efficiency, fan efficiency, resistance, aerodynamic system, boiler power limits.

\section{References}

1. Basharov M.M. (2011) Energosberegayuschaya modernizatsiya rektifikatsionnoy ustanovki vyideleniya fenola. Neftegazovoe delo, No 2, 136-146.

2. Laptev, A.G., Nikolaev, N.A., Basharov, M.M. (2011) Metody intensifikatsii i modelirovaniia teplomassoobmennykh protsessov. Uchebno-spravochnoe posobie. Moscow: Teplotehnik, $335 \mathrm{p}$.

3. Krachunov, Hr. (2010) Kompleksno proektirane na tehnicheski sistemi. Tehnicheski universitet, Varna.

4. Arsiriy, V.A., Arsiriy, O.O., Smirnova, V.O. (2016) Increasing Productivity of the Boiler by Eliminate the Limited Capacity of the Thrust and Blow. NTU "KhPI" Bulletin: Power and heat engineering processes and equipment, iss. 10, 78-84. doi: https://doi.org/10.20998/2078-774x.2016.10.12

5. Trembovlya V.I., Finger E.D., Avdeeva A.A. (1977) Teplotehnicheskie ispyitaniya kotelnyih ustanovok. Moscow, Energiya, 296 p.
6. Idelchik, I.E., Shteynberg, M.O. (1998) Handbook of hydraulic resistance. Engineering, 672 p.

7. Maisotsenko, V.S., Arsiri, V.A. (1998) PST 5.812.423 USA Method of determining for working media motion and designing flow structures for same. Publ. 22.09.1998.

8. Butenko, A.G., Smyik, S.Yu. (2015) Pidvischennia koefitsienta korisnoi dii tsentralnogo ezhektora za neoptimalnikh rezhimiv roboty. Naukoviy visnik Natsionalnogo girnichogo universitetu, No 2, 57-61.

9. Abdulin, M.Z., Dubovik, V.S. (2004) Struynonishevaya tehnologiya szhiganiya topliva na ob'ektah nergetiki. Novosti teplosnabzheniya, No 11, 19-22.

10. Fillipov, G.A., Melamed, L.E., Tropkina, A.I. (2010) Ierarhiya modeley analiza kollektornyih sistem i makromasshtabnyiy analiz. Problemyi energetiki, No 5-6, 3-16. 